\title{
Mineralized biosignatures in ALH-77005 Shergottite - Clues to Martian Life?
}

https://doi.org/10.1515/astro-2019-0002

Received Mar 19, 2018; accepted Aug 16, 2018

\begin{abstract}
The ALH-77005 Martian meteorite was found in Allan Hills on Antarctica during the Japanese National Institute of Polar Research (1977-1978) mission. One thin section sample was studied by optical microscopy for microtexture and by FTIR-ATR microscopy for interpretation of biogenic minerals and embedded organic materials. The geochemical data (biogenic elements, $\delta^{13} \mathrm{C}$ ) of ALH-77005 meteorite from literature implementing recent results were compared to terrestrial geological samples. The ALH-77005 has poikilitic textures with coarse pyroxenes and brown olivines, and with recrystallized melt pocket. The coarse-grained minerals do not contain any alteration along the grain boundaries. Melt pocket and vicinity of opaque minerals contain biogenic signatures as filamentous, coccoidal forms of iron-oxidizing bacteria. The biosignatures were determined by 1) coccoidal, filamentous forms, 2) presence of embedded organic material, 3) presence of biogenic minerals, like ferrihydrite, goethite, and hematite. The other signatures for biogenicity of this meteorite are strong negative $\delta^{13} \mathrm{C}$, enrichment of $\mathrm{Fe}, \mathrm{Mn}, \mathrm{P}, \mathrm{Zn}$ in shock melt support scenario. This study proposes presence of microbial mediation on Mars.
\end{abstract}

Keywords: Martian meteorite, biogenic signatures, iron oxidizing bacteria (FeOB), ALH-77005, shergottite, FTIR-ATR, microbial mediation

\section{Introduction}

The ALH-77005 Martian meteorite was found in the Allan Hills, in South Victoria Land on Antarctica in 19771978 (Yanai, 1979). Nyquist et al. (2001) indicated lherzolitic texture of ALH-77005. Moreover, Ikeda (1994) suggested that the origin of this meteorite and its shergot-

Corresponding Author: Ildikó Gyollai: Institute for Geological and Geochemical Research, Research Centre for Astronomy and Earth Sciences, Geobiomineralization and Astrobiology Working Group, HAS, H-1112 Budapest, Budaörsi u. 45, Hungary; Email: rodokrozit@gmail.com, gyildi@gmail.com

Márta Polgári: Institute for Geological and Geochemical Research, Research Centre for Astronomy and Earth Sciences, Geobiomineralization and Astrobiology Working Group, HAS, H-1112 Budapest, Budaórsi u. 45, Hungary

Szaniszló Bérczi: Eötvös University, Dept. of Materials Physics, Cosmic Materials Space Res. Group, H-1117 Budapest, Pázmány P. str. 1/a, Hungary; Email: bercziszani@caesar.elte.hu

Arnold Gucsik: Eszterházy Károly University, Dept. of Natural Geography and Geoinformatics, 3300 Eger, Leányka str. 6, Hungary; Wigner Research Centre for Physics, HAS, 1121 Budapest, KonkolyThege M. str. 29-33, Hungary; University of Johannesburg, Department of Geology, 2600 Auckland Park, Johannesburg, South Africa; Email: ciklamensopron@yahoo.com

Elemér Pál-Molnár: Szeged University, Dept. of Mineralogy, Geochemistry and Petrology, 6722 Szeg, Hungary

əopen Access. () 2019 I. Gyollai et al., published by De Gruyter. (cc) BY License tite formation with shallow magma reservoir (such as lava lake) is on Mars. The aim of this study is to investigate potential mineralized biosignatures in the spinifex textured melt pockets. The petrographical, petrological composition and shock metamorphic features were described by Ikeda (1994); Nagy et al. (2012); Gyollai et al. (2013).

\subsection{Importance of microstructure, aspects of biogenicity}

Concerning occurrence of biosignature-like objects in meteorites the most obvious case is terrestrial contamination, and in the frame of this the comparison with terrestrial biogenicity aspects is suggested.

Biogenicity in terrestrial systems is very important question as well. Recent analogies are also used for interpretation of geological samples. But, the interpretation of biosignature in geological scale (Ga-My) is not easy, diagenesis and other processes can overprint microbial features. The following are features proposing microbial origin in geological samples (Cady et al., 2003):

1. microbial microtexture: filamentous, coccoid like, vermiform, brain-like and stromatolite-like macrotexture - fine lamination multiple cyclicity;

This work is licensed under the Creative Commons Attribution 4.0 

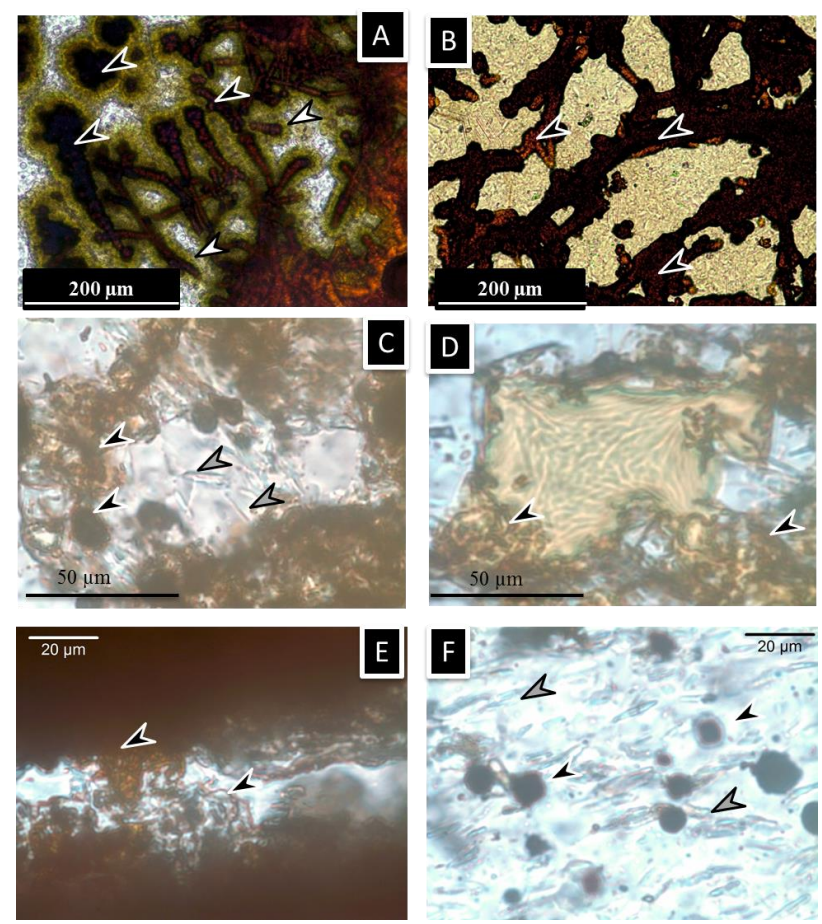

Figure 1. Terrestrial examples for microbial mediation. A: Filamentous Fe-oxide-hydroxide-bearing biosignatures formed most probably by iron-oxidizing bacteria ( $\mathrm{FeOB}$ ) (black arrow) in quartz from Mátra Mountains and celadonite- and organic matter-bearing mineralized EPS (greenish halo) around the filamentous biosignature (white arrow) (15 My) (Müller, 2009). B: Filamentous goethitebearing biosignatures formed most probably by iron-oxidizing bacteria (FeOB) (black arrow) in quartz from Úrkút, Csárdahegy (190 My) (Polgári et al., 2012a,b). C: coccoidal and filamentous FeOB (black arrows) with cyanobacteria (gray arrows) (635 Ma, Naraachamspos, Namibia). D: Bioweathering of chlorite by filamentous FeOB (black arrows) (635 Ma, Naraachamspos, Namibia) (Gyollai et al., 2017a). E: Filamentous FeOB (black arrow) from Sesfontain-Opuwo (750 Ma, Namíbia) F: coccoidal FeOB (black arrow) and cyanobacteria (grey arrow) from Sesfontain-Opuwo (750 Ma, Namíbia) (Gyollai et al., 2015).

2. bioindicator minerals (Skinner, 2005) which can be modified by diagenetic and other processes;

3. presence of organic matter (Polgári et al., 2012a; Gyollai et al., 2015; Bodor et al., 2016; Rajabzadeh et al., 2017; Molnár et al., 2017);

4. biosignatures like isotope signals ("vital effect") (C, $\mathrm{S}, \mathrm{N}, \mathrm{Fe}$, etc.), shape of minerals, and selective enrichment of bioessential elements ( $\mathrm{Fe}, \mathrm{Mn} \mathrm{Zn}$, As, Be, U, P) (Polgári et al., 2012a; Gyollai et al., 2017a, etc.);

5. recent analogies of biomineralization, biomarker organic matter;

6. paleoenvironmental analogies (sedimentary, etc.);

7. preservation.
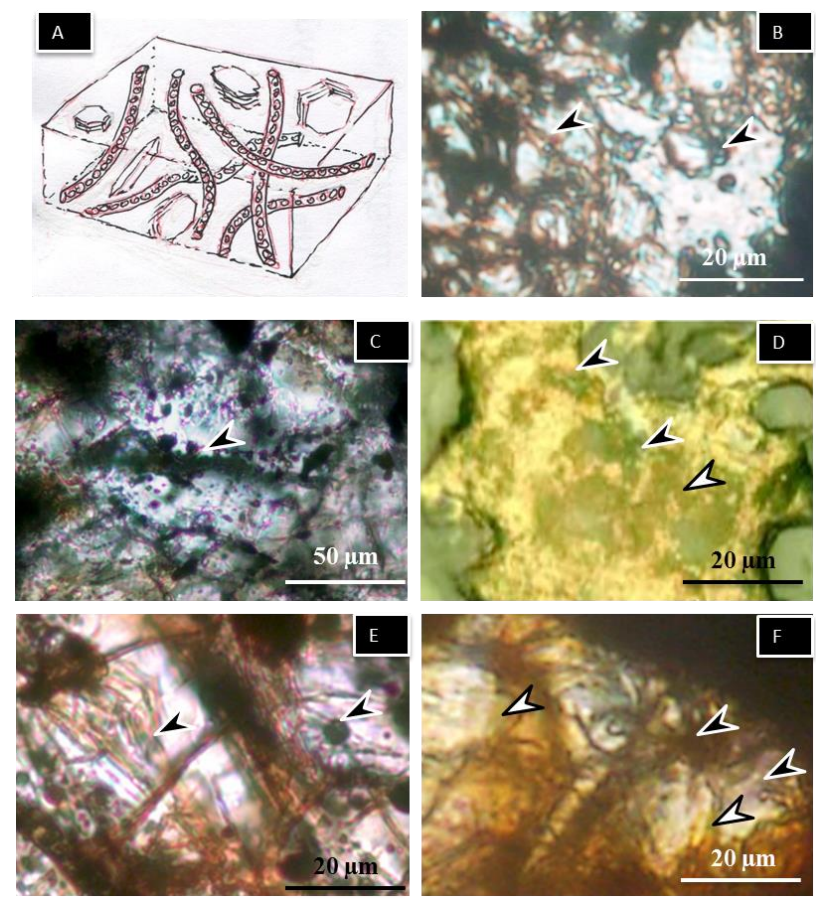

Figure 2. Microbially mediated mineralized biosignatures in meteorites fallen in Hungary (Mező-Madaras, Knyahinya, Mócs, Nyírábrány and Kaba) (Polgári et al. 2017a,b, Polgári et al. 2018a, this volume). A: Sketch of microbial features (Bérczi, personal comm. 2017). B: microbial features in Kaba CV3 meteorite (black arrows). C: Coccoidal FeOB in Knyahinya $\mathrm{L} 5$ sample (black arrow). D: Microbial mediation of troilite by filamentous FeOB (black arrows) with clay mineralization of EPS (white arrow) in Mócs L6 chondrite (reflected light) E: Alteration of olivine by filamentous and coccoidal FeOB in Mezőmadaras L3 chondrites. (black arrows) (transmitted light). F: Microbial mediation of Nyírábrány LL5 chondrite by filamentous FeOB (black arrows) with clay mineralization (white arrows) (transmitted light).

The following methods are suggested to study the above mentioned biosignatures:

(i) High resolution polarization microscopy by magnification of 40x, 100x, 200x, 400x, 1000x for identification of both textural and micromorphological features of biomineralization.

(ii) Spectroscopical methods for in situ determination of biominerals and embedded organic material (Raman spectroscopy, ATR-FTIR spectroscopy, Gas Cromatograph-Mass Spectrometry).

(iii) Determination of isotope signals (C, S, Fe) by Mass Spectrometry.

(iv) Complex interpretation of data (The multihierarchical analysis is introduced by Bérczi 2017, 2018).

The textural features play important role to study biomineralization, and Fe biomineralization gives information concerning paleoenvironmental circumstances. 


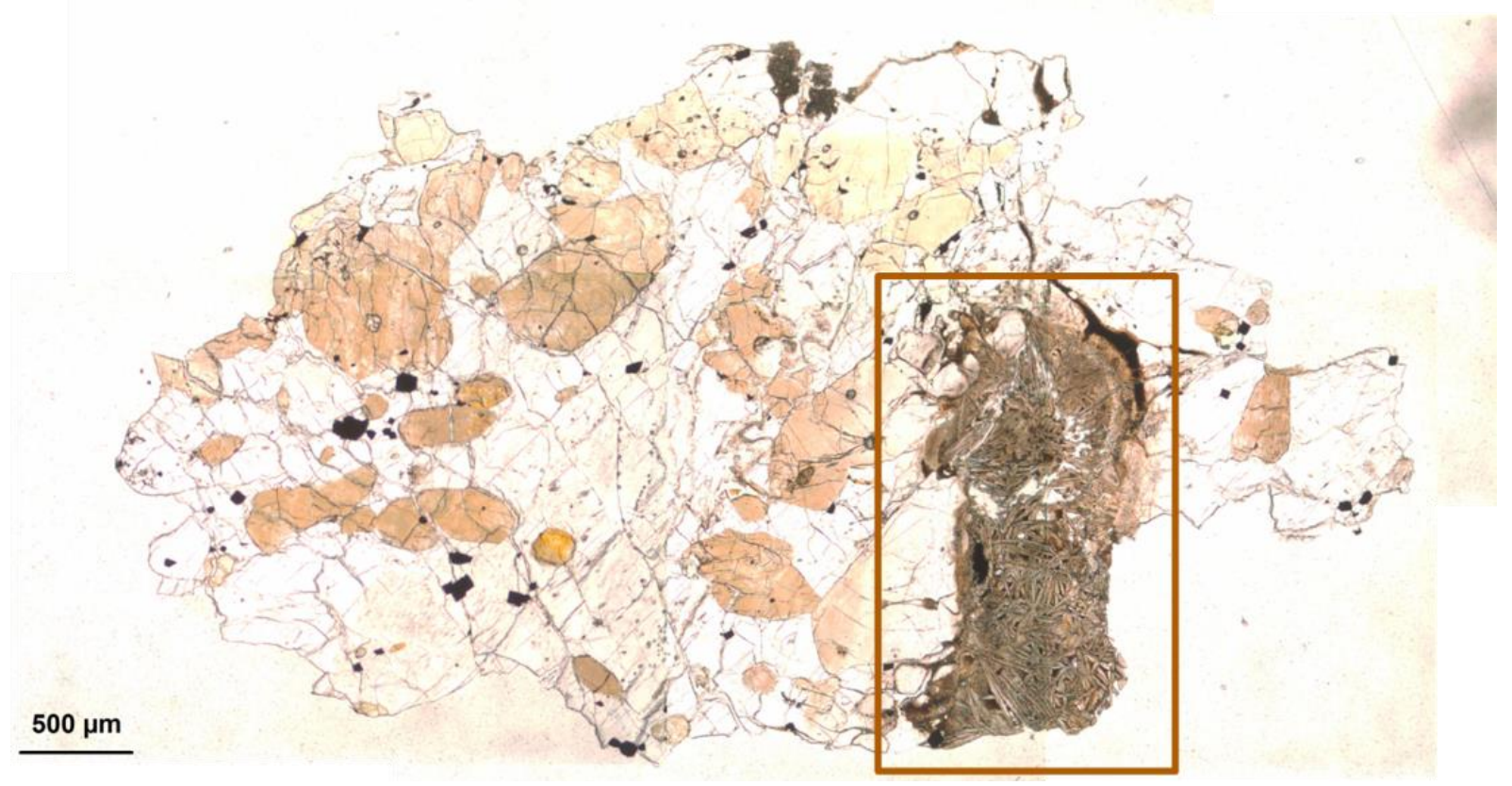

Figure 3. Thin section of ALH-77005 in plane polarized light. The studied area by FTIR spectroscopy is marked by rectangle, where the strong putative microbially mediated alteration was observed.

Thus, after morphological observation, identification of minerals in mineralized microbially produced textures is needed (Polgári et al. 2012b, MMPT, Gyollai et al. 2015, 2017a). These mineralized biosignatures have a greater chance to survive over geological timescale (MyGa yrs) (Baele et al., 2008). Metastable biominerals alter to more stable phases (e.g. ferrihydrite à goethite à hematite), so, the complex interpretation by combination of morphology-, mineralogy- and chemistry bioindicators is proposed (Baele et al., 2008).

Moreover, complex interpretation needs multihierarchical system analyses of microbial mediation and biomineralization. For example, the morphological biosignatures for comparison are obtained from terrestrial and meteorite samples from preliminary studies (Figures 1-2, Müller 2009, Polgári et al. 2012a, b, 2017a, b; Gyollai et al. 2017a,b). The mineralized microbially mediated microtexture can be observed as filamentous, coccoid-like, vermiform, woven, brain-like forms by polarization microscopy by 400x and 1000x magnification (Figures 1-2). Complex interpretation by multihierarchical analyses, like biominerals, bioessential elements, organic material, light $\mathrm{C}$ isotopic features support this interpretation for both terrestrial (Polgári et al., 2012a,b, 2018a; Gyollai et al., 2015; Bodor et al., 2016; Rajabzadeh et al., 2017; Molnár et al., 2017) and in meteorite samples (Gyollai et al., 2017b; Polgári et al., 2017a,b).

\section{Methods}

The FTIR-ATR measurements and optical microscopy were performed at HAS Research Centre for Astronomy and Earth Sciences, IGGR. The mineral assemblages and textures were characterized by a NICON Eclipse LV600POL optical microscope with magnification 40x, 100x, 200x, 400x and 1000x. We used Bruker Vertex70 with Hyperion 2000 FTIR-ATR microscope with a 20x ATR objective and MCT-A detector, with spatial resolution of $2 \mu \mathrm{m}$, for the determination and distribution of micro-mineralogy and organic compounds. During the infrared analysis, the minerals in the thin section were contacted by the tip of the germanium (Ge) crystal (selected $1 \mathrm{~N}$ pressure) of 100 $\mu \mathrm{m}$ in diameter with spatial resolution of $2 \mu \mathrm{m}$. All measurements were performed for 32 scans at $4 \mathrm{~cm}^{-1}$ resolution in the $600-4000 \mathrm{~cm}^{-1}$ range. Bruker Optics' Opus 5.5. software was used for manipulation of the resultant spectra (e.g. baseline correction, atmospheric compensation etc.). To avoid the interpretation of environmental conditions of the measurements in the sample, the spectra of dichloromethane, glass rode were used as background. The measurements were done on $35 \mu \mathrm{m}$ thick thin section (Figures 3-4). A total 77 of spectra were acquired. 


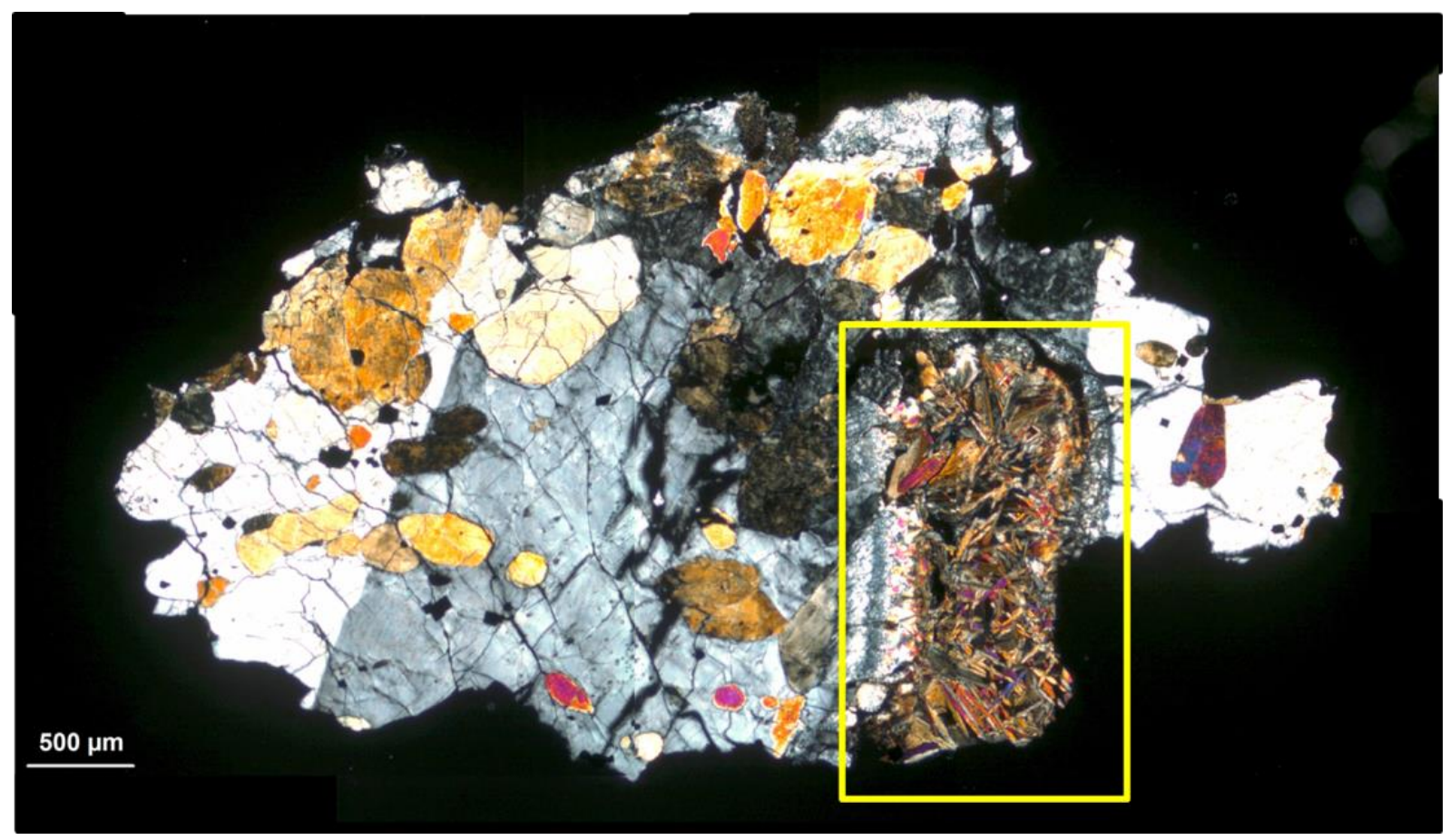

Figure 4. ALH-77005 thin section with crossed polars: poikilitic texture of olivine with pyroxene cumulate grains, the studied melt pocket (rectangle) mostly composed of olivine.
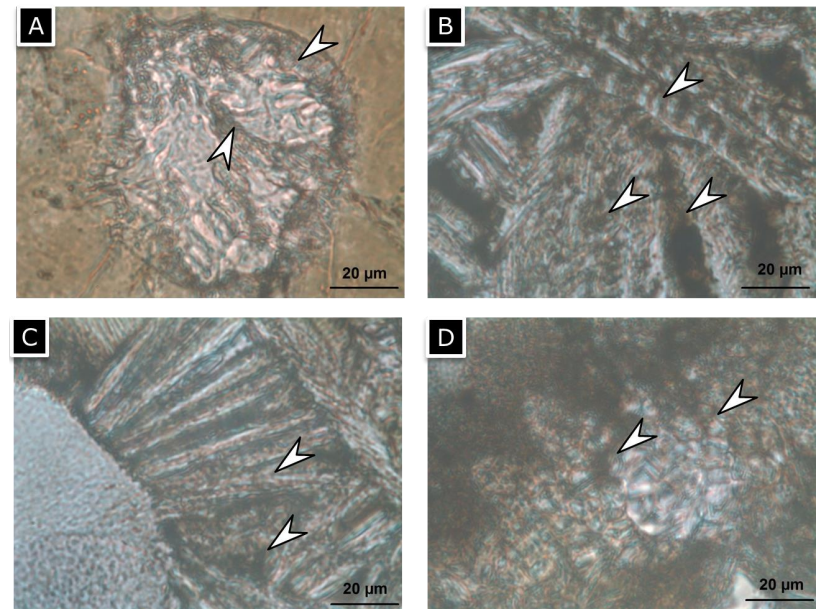

Figure 5. Putative mineralized microbially mediated biosignatures in ALH-77005 meteorite (arrows). The coarse crystals do not contain microbially mediated textures, only near troilite and in melt pocket were detected filamentous, necklace-like iron-oxide-containing textural features resembling to microbially mediated biosignatures, similarly to the influence of iron-oxidizing microbes (transmitted light). A: Coccoidal iron-oxiding bacteria (FeOB) in melt inclusion of brown olivine. B: Filamentous FeOB in melt pocket. $\mathrm{C}$ : $\mathrm{FeOB}$ along crystallite needles $\mathrm{D}$ : $\mathrm{FeOB}$ with organic material in melt pocket. The signs of $\mathrm{FeOB}$ are marked by arrows.

\section{Results}

\subsection{Petrography}

The ALH-77005 consists of pyroxene, olivine and feldspar. The ALH-77005 has coarse-granular texture with locally microgranular and poikilitic texture regions and melt pockets with recrystallized needle-like crystallites in glassy matrix.

In the environment of melt pockets resorption rim can be observed with toast-like texture in some cases and infiltration of dark melt. The melt pockets are darker (darkbrown-black in plane polarized lights) than its environment (well-crystallized coarse crystals).

In the vicinity and inside of melt pockets several textures can be observed. The needle-like crystals are feldspar and pyroxene in melt pockets. The lengths of needles are between 10-75 $\mu \mathrm{m}$, and their width falls into $1-5 \mu \mathrm{m}$ range.

Near to melt pockets, isotropic lath-shaped plagioclase, maskelynite occur. But, according to presence of weak feldspar band of Raman and FTIR spectra, this alteration is transient, the shock pressure did not exceed 30 GPa. In the olivines, parallel to the fractures, kink-band system can be observed. The poikilitic fractured pyroxene grain contains olivine with thick one-set kink bands. 
Table 1. Vibration bands of organic material and minerals with references.

\begin{tabular}{|c|c|c|c|c|c|c|c|c|c|c|c|c|c|}
\hline Mineral phase & References & $\begin{array}{c}\text { Measuring area ID } \\
\text { Total No. of spectra } \rightarrow \\
\text { Wavelength }\left[\mathrm{cm}^{-1}\right]\end{array}$ & $\begin{array}{l}1 \\
4\end{array}$ & $\begin{array}{l}2 \\
7\end{array}$ & $\begin{array}{c}3 \\
12\end{array}$ & $\begin{array}{l}4 \\
6\end{array}$ & $\begin{array}{l}5 \\
7\end{array}$ & $\begin{array}{l}6 \\
8\end{array}$ & $\begin{array}{l}7 \\
7\end{array}$ & $\begin{array}{l}8 \\
9\end{array}$ & $\begin{array}{l}9 \\
8\end{array}$ & $\begin{array}{c}10 \\
3\end{array}$ & $\begin{array}{c}11 \\
6\end{array}$ \\
\hline olivine & $\begin{array}{l}\text { Dyar et al. 2011; Lane et al. } \\
\text { 2011 }\end{array}$ & $\begin{array}{c}602,833,864,930 \text { sh, } \\
986\end{array}$ & 4 & 2 & 1 & 2 & 7 & 8 & & & & & \\
\hline augite & Dyar et al. 2011 & $\begin{array}{c}649,705,729,848 \\
920,1003,1055\end{array}$ & 5 & 10 & 4 & & & & & & & & \\
\hline diopside & Dyar et al. 2011 & $870,920,1060$ & & & & & & & 7 & 9 & & & 1 \\
\hline enstatite & Dyar et al. 2011 & $\begin{array}{c}625,680,740,854 \\
940,1000,1040\end{array}$ & & & & & & & & & 8 & & \\
\hline albite & Müller et al. 2014 & $798,950,1000$ & & & & & & & & & & & \\
\hline anorthite & Müller et al. 2014 & $720,940,1000$ & & & 1 & & & & & & & & 2 \\
\hline ferrihydrite & Glotch \& Rossman 2009 & $692,878,960,3400$ & & & & & & & & & & 3 & 2 \\
\hline lepidocrockite & Glotch \& Rossman 2009 & $602,748,895,1023$ & & & & & & & & & & & 1 \\
\hline Organic compounds & & & & & & & & & & & & & \\
\hline$v C=C / C-O$ & Parikh \& Chorover 2006 & $1070-1240$ & & & & & & & & & 8 & & \\
\hline vs CO & Parikh \& Chorover 2006 & $1360-1450$ & 4 & & & 6 & & 8 & 7 & 9 & 8 & & \\
\hline $\mathrm{d} \mathrm{CH} 2$ & Parikh \& Chorover 2006 & $1454-1482$ & 4 & & & 6 & & 8 & 7 & 9 & 8 & 3 & 5 \\
\hline $\mathrm{C}-\mathrm{N}, \mathrm{CH}$ deformation & Parikh \& Chorover 2006 & 1526 & 4 & 7 & 12 & 6 & 7 & 8 & 7 & 9 & 8 & 3 & 5 \\
\hline C-N N-H amide II & Parikh \& Chorover 2006 & $1540-1550$ & 4 & 7 & 12 & 6 & 7 & 8 & 7 & 9 & 8 & 3 & 5 \\
\hline $\mathrm{C}=\mathrm{C}$ asym. Stretch & Parikh \& Chorover 2006 & 1598 & & & & 6 & & & & & & & \\
\hline $\begin{array}{c}\text { amide I } \mathrm{C}=\mathrm{O}, \mathrm{C}-\mathrm{N}, \\
\mathrm{N} \_\mathrm{H}\end{array}$ & Parikh \& Chorover 2006 & $1632-1652$ & 4 & 7 & & & 7 & 8 & 7 & 9 & & 3 & \\
\hline $\mathrm{v}$ as $\mathrm{COOH}$ & Parikh \& Chorover 2006 & $1720-29$ & 4 & & & & & & & & & & \\
\hline $\mathrm{CO}$ & Müller et al. 2014 & 2343 & 4 & 7 & 12 & 6 & 7 & 8 & 7 & 9 & 8 & 3 & 6 \\
\hline $\mathrm{CO}$ & Müller et al. 2014 & 2365 & 4 & 7 & 12 & 6 & 7 & 8 & 7 & 9 & 8 & 3 & 6 \\
\hline $\begin{array}{c}\text { C-H sym. Stretch } \\
\mathrm{CH} 2\end{array}$ & Parikh \& Chorover 2006 & 2853 & 4 & & & & 7 & 8 & 7 & & 8 & & \\
\hline $\begin{array}{c}\text { C-H asym. Stretch } \\
\mathrm{CH} 2\end{array}$ & Parikh \& Chorover 2006 & 2926 & 4 & & & 4 & 7 & 8 & 7 & 9 & & 3 & \\
\hline $\mathrm{OH}$ & Madejová \& Komádel 2001 & $3230-3700$ & 4 & & & 4 & 7 & & 7 & 9 & 8 & & \\
\hline
\end{tabular}

\subsection{Mineralized putative biosignatures in ALH-77005 meteorite}

The recrystallized shock melt with spinifex texture contains putative microbially mediated features as well resembling to mineralized microbially produced texture (MMPT) - in the form of pearl necklace-like textures with vermiform inner signatures, which are embedded in needle-like crystals (olivine, pyroxene, feldspar) in the rapidly cooled shock melt (Figure 5). The coarse minerals do not contain microbially mediated texture. It occurs only near to opaque minerals and in shock melt pocket.

The MMPT consists of micrometer-sized microbial filamentous elements and clusters in their boundary region. The MMPT is very extensive, reaches $70-80$ vol. $\%$ of the shock melt pocket and is intimately woven in the full crosssection of the melted part. All of recrystallized melt pocket sections showed signs of Fe mobilization and oxidation (brown haloes around mineral grains, brown filaments, Figure 5).

\subsection{FTIR-ATR microscopy}

Ferrihydrite, goethite and organic material were detected in melt pocket with low-Ca pyroxene and olivine by FTIRATR microscopy (Table 1, Figure 6). The iron-oxide-bearing microbial textures have a mixed composition containing iron-oxides (ferrihydrite, goethite) (Glotch \& Rossman, 2009), and olivine (Matrajt et al., 2005). Hydrocarbon compounds were also detected (long chain hydrocarbon, diene) (Parikh \& Chorover, 2006; Müller et al., 2014; Orlov et al., 2012), and C-H stretching of aliphatic hydrocarbons (Parikh \& Chorover, 2006) (Figure 6). The presence and appearance of ferrihydrite corresponds to microbially originated remobilization (consumation) and remineralization of iron from olivine and troilite. IR vibrations of isoprenoids were also detected (Orlov et al., 2012). 

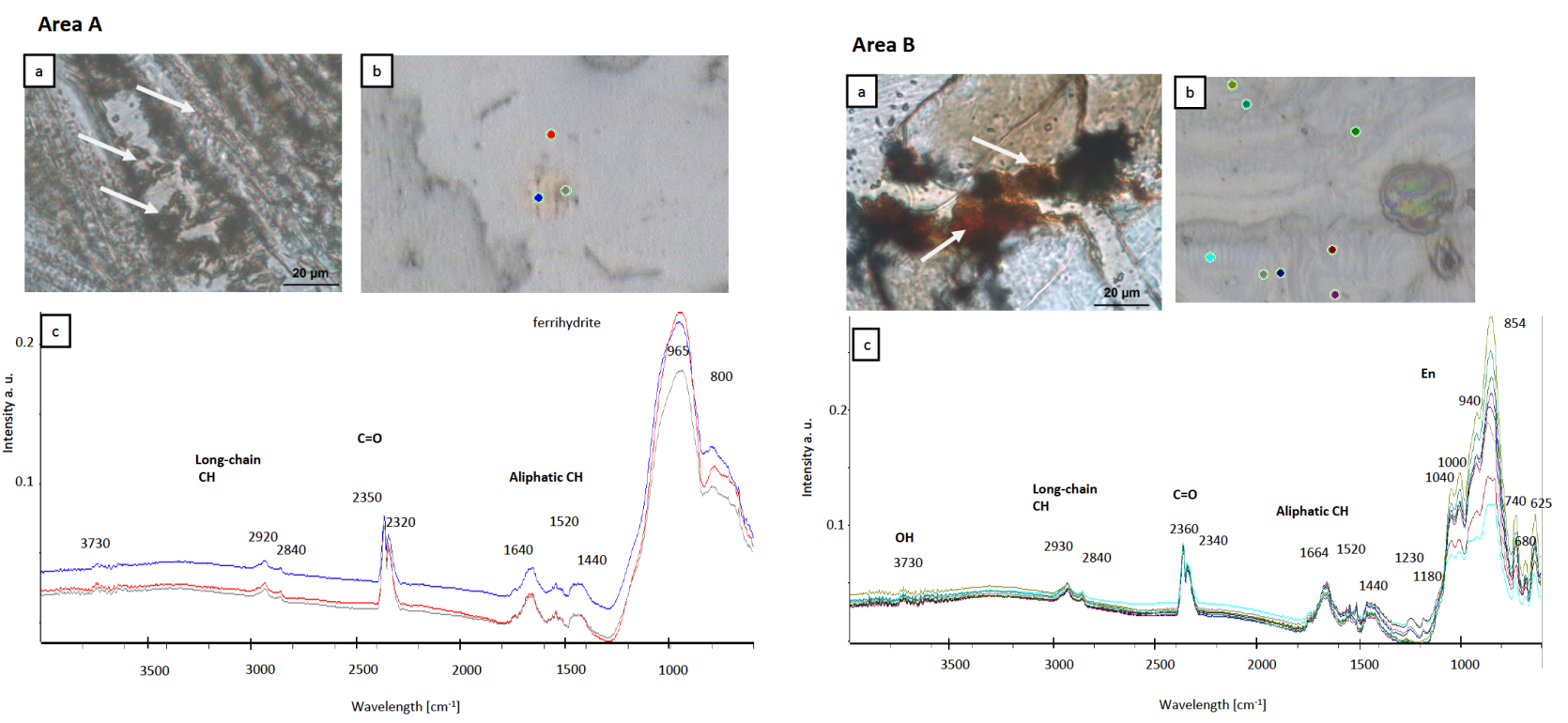

Figure 6. Area (A) a) Filamentous pearl necklace-like inner textures (marked by arrows) in shock melt pocket; Area (B): a) Microbially mediated mobilization and mineralization of iron from opaque minerals and organic material. IR spectra of area near troilite (degradation to ferrihydrite) and pyroxene with organinc compounds of biosignatures. Area (A) and (B) b) measuring points of FTIR spectra; c) Spectra were taken in shock melt pocket. The peak positions are marked by numbers above the spectra, and vibration types are written by bold letters. Legend: En=enstatite.

\section{Discussion}

The brown signature of melts and olivine could be caused by magnetotactic bacteria (Hoffmann et al., 2008), which has 0.4-0.7 wt.\% MnO (Ikeda, 1994) as bioessential element which support our scenario. The low Ca pyroxenes also contain 0.4-0.6 wt.\% MnO (Ikeda, 1994). The dark melt has 19-26 wt.\% FeO and 0.4-0.7 wt.\% MnO (Edmunson et al., 2002), which are bioessential elements of iron oxidizing bacteria. The $\mathrm{P}_{2} \mathrm{O}_{5}$ content in melt pockets varies between 3-5 wt.\% (by melt of apatite and whithlockite) (Calvin \& Rutherford, 2005), which is a essential chemical component for microbial activity and could also be consumed as nutrient for iron oxidizing bacteria. The mentioning of signature for Martian life was mentioned by Mikouchi et al. (1997), who found PAHs and magnetotactic nanobacteria structured microfossils with biominerals troilite pyrite and carbonate in ALH-84001 meteorite. Our recent results fit well with their interpretation, similarly to Mikouchi et al. (1997), these features were found in melt pocket and near pyrite - troilite grains of ALH-77005 meteorite: organic material, morphology, biogenic minerals were found. The troilite grains contain $0.04 \mathrm{wt} . \% \mathrm{Zn}$ based on Ikeda (1994), which could solve as nutrient for iron oxidizing bacteria.

Noble gas compositions, cosmic-ray exposure age (2.9 $\pm 0.7 \mathrm{my})$, and K-Ar age $(1.33 \pm 0.13$ by) are obtained by Miura et al. (1995) for ALH-77005 shergottite. However, they mentioned, that this meteorite is heavily contaminated by elementally fractionated gases - which were proposed by microbial alteration of terrestrial origin. But comparing the textures to the secondary terrestrial alteration should follow the fractures and grain boundaries, but in our sample, the microbial alteration was observed mostly in melt pocket, the fractures of coarse silicates remained clear. Alternatively, Takenouchi et al. (2018) suggest formation of brown olivine by heterogeneous shock p-T conditions, where Fe-rich nanoparticle formed along crystal defects of shocked olivine due to shear stress during impact event: the high pressure phases (ringwoodite, wadsleyte) backtransformed to olivine during the decompression. However, this interpretation does not fit with the complex filamentous microbial microtexture.

Wright et al. (1992) measured negative $C$ isotope values for SNC meteorites, where $\delta^{13} \mathrm{C}$ of ALH-77005 is -36\% (for further meteorites data are the following: Zagami $\delta^{13} \mathrm{C}:-34 \% \mathrm{ffl}$, Nakhla $\delta^{13} \mathrm{C}:-31 \% \mathrm{ffl}$, Shergotty $\delta^{13} \mathrm{C}:-31$ $\% \mathrm{ffl}$, -Lafayette $\delta^{13} \mathrm{C}$ : $\left.-29 \% \mathrm{ffl}\right)$. The carbonate fraction of EETA 79001 reach $-25 \%$ ffl (Wright et al., 1988). The negative $\delta^{13} \mathrm{C}$ imply organic carbon contribution supporting biogenicity (Polgári et al., 2012a).

The iron-rich smectites in nakhlites (Hicks et al., 2014) could be formed by diagenesis of mineralized extracellular polymeric substance (EPS) of FeOB, as occur in terrestrial 
environment (Müller, 2009; Polgári et al., 2012a,b), and observed in other meteorites (Polgári et al., 2017a,b, 2018a, 2019, Kaba, Nyírábrány, Mócs, Knyahinya, Mezőmadaras).

Comparing our results to biogenicity aspects, our data confirm:

Dense and invasive microbially mediated processes in the ALH-77005 meteorite, supported by microtexture, micromineralogy, embedded organic compounds, and enrichment of bioessential elements, which effected most of the mass of the melted pocket of the sample. Also, strongly negative $\delta^{13} C$ values as "vital effect" support this scenario. These fit well on 5 hierarchical levels (isotope, element, molecule, mineral and texture) with complex terrestrial biogenicity features, and also results on other meteorites (Polgári et al., 2017a,b, 2018a, 2019, Kaba, Nyírábrány, Mócs, Knyahinya, Mezőmadaras). In the case of these meteorites, the complex dense biosignatures affected most of the mass (up to $80 \%$ ) of the samples, which raised that if the biosignatures are terrestrial contamination, it is of no effect to interpret the so called transformation products happened on the parent body, as it is a general custom based on literature. This arises a contradiction: how could it be that all these classical transformations have been occurred to happen on the parent bodies, while the microbial processes happened separately, in terrestrial conditions, although the MMTP had interwoven all the textural and mineralogical assemblage (Polgári et al., 2019).

Comparing recent results and interpretation with other meteorites, it can be raised, that on these similarities the microbially mediated biosignatures can be proposed microbial mediation by FeOB on Mars.

\section{Conclusion}

The microbial alteration occur only in recrystallized shock melt pocket and near to opaque minerals. Microbial mediation along rims and fractures of coarse grains are not present, which dismiss the terrestrial alteration origin. The microbial mediation by FeOB is supported by 1) morphology (coccoidal, filamentous form of $\mathrm{FeOB} ; 2$ ) presence of embedded organic material (aliphatic $\mathrm{CH}, \mathrm{PAHs}$ ); 3) enrichment of bioessential elements (Fe, $\mathrm{Mn}, \mathrm{P}, \mathrm{Zn}$ ); 4) negative $\delta^{13} \mathrm{C}$ values $(-36 \% \mathrm{ffl})$. The other Martian meteorites have similarly strong negative $\delta^{13} \mathrm{C}$ values (-29- - $\left.36 \% \mathrm{ffl}\right)$ and alteration by Fe-rich clays, iron-oxi-hydroxides.

Comparing recent results and interpretation with other meteorites, it can be concluded, that on these similarities the microbially mediated biosignatures can be proposed microbial mediation by FeOB on Mars.

\section{Highlights}

- Putative filamentous iron oxidizing bacteria were found in shock melt pocket of shergottite.

- Biosignatures were determined by optical microscopy and by FTIR-ATR.

- Bioessential elements and carbon isotope data from references support biogenicity.

- Comparison of similar results of Mező-Madaras, Mócs, Knyahinya, support biogenicity on Mars.

Acknowledgment: We are grateful to H. Kojima for the loan of ALH-77005 sample, and to RCAG IGGR HAS for instrumental support. The authors thank the support of National Research, Development and Innovation Office, National Scientific Research Found No. 125060.

\section{References}

Bishop, J. L. \& Murad, E. 2004, J. of Raman Spect., 35 (6), 480-486. Baele, J. M., Bouvain, F., De Jong, J., Matielli, N., Papier, S., \& Préat, A. 2008, In Instruments, Methods, and Missions for Astrobiology XI, International Society for Optics and Photonics, 7097, $70970 \mathrm{~N}$.

Bérczi, S., 2017, In: Planetary Science Vision 2050 Workshop (27-28 February and 1 March, 2017 in Washington, DC, USA), 1989, id. 8003 .

Bérczi, S., 2018, Acta Geoscientia Debrecina Special Issue 1, 31-53 (in Hungarian, with the captions of the figures in English).

Bodor, S., Polgári M., Szentpétery, I., \& Földessy, J. 2016, Ore Geol. Revs., 72, 391-401.

Cady, S.L., Farmer J.D., Grotzinger, J. P., Schopf, J. W., \& Steele, A. 2003, Astrobiology, 3 (2), 351-369.

Calvin, C. \& Rutherford, M. J. 2005, $36^{\text {th }}$ LPSC. \#abs1895.

Dyar, M. D., Glotch, T. D., Lane, M. D., Wopenka, B., Tucker J. M., Seaman, SJ. et al. 2011, Polar Science, 4(4), 530-549.

Edmunson, J., Borg, L. E., Shearer, C. K. \& Papike, J. J. 2002, 33 ${ }^{\text {rd }}$ LPSC. abs\#1844.

Glotch, T. D. \& Rossman, G. R., 2009, Icarus, 204(2), 663-671.

Gyollai, I, Polgári, M. , Bérczi, Sz. , Veres, M. , Gucsik A., \& PálMolnár, E. 2017b, Workshop on Chondrules and Protoplanetary Disk, \#1963.

Gyollai, I., Polgári, M., Fintor, K., Popp, F., Mader, D., Nagy, Sz. et al. 2015, J. Earth \& Env. Sci., 10(1), 63-76.

Gyollai, I., Nagy, S., Bérczi, S. \& Nishido, H. 2013, In: 4th Symp. Nat. Inst. Polar Sci. - Antarctic Meteorites ordinary session, 2.

Gyollai, I., Polgari, M., Fintor, K., Pál-Molnár, E., Popp, F., \& Koeberl, C. 2017a, Austr. J. Earth Sci., 110(1), 2-18.

Gyollai, I., Polgári, M., Veres, M., Nagy, S., Popp, F., Mader, D. et al. 2014, Comm. Nam. Geol. Surv., 15, 117-133.

Hicks, L. J., Bridges, J. C., \& Gurman, S. J. 2014, Geochim. Cosmochim. Acta, 136, 194-210.

Hoffmann, V. H., Funaki, M., Torii, M., Kurihara, T. \& Mikouchi, T. 2008, $39^{\text {th }}$ LPSC \#1703. 
Ikeda, Y. 1994, Proc. of NIPR Symp. of Ant. Met. Res. (31st of May2nd June 1993, Tokyo, Japan), 7, 929.

Lane, M. D., Glotch, T. D., Dyar, M. D., Pieters, C. M., Klima, R., Hiroi, T. et al. 2011, J. Geophys. Res.: Planets, 116(E8).

Madejova, J. \& Komadel, P. 2001, Clays \& Clay Miner., 49(5), 410432.

Matrajt, G., Caro, G. M., Dartois, E., d'Hendecourt, L., Deboffle, D. \& Borg, J. 2005, 433(3), 979-995.

Mikouchi, T., Tsuchiyama, A., Akai, J., Nakashima, S., Tazaki, K., Itaya, T. et al. 1997, Miner. Journ., 19(2), 47-64.

Miura, Y. N., Nagao, K., Sugiura, N., Sagawa, H. \& Matsubara, K. 1995, Geochim. Cosmochim. Acta, 59(10), 2105-2113.

Molnár, Z., Polgári, M., Hein, J.R., Józsa, S., Fekete, J., Gyollai, I., Fintor, K., Bíró, L., Szabó, M., Rapi, S, \&. Forgó, P. 2017, Fe-Mn oxide indications in the feeder and mound zone of the Jurassic Mn-carbonate ore deposit, Úrkút, Hungary. Ore Geol. Revs., 86, 839-855.

Müller, A. 2009, Morphology and genesis of chalcedony and opal in S-Mátra Mts. Dél-mátrai kalcedon és opál mintázatok morfológiája és genetikája. Manuscript, 110. (in Hungarian).

Müller, CM., Pejcic, B., Esteban, L., Delle Piane, C., Raven, M., \& Mizaikoff, B. 2014, Sci. Reps. 4, article no. 6764.

Nagy, Sz., Józsa, S., Gucsik, A., Bérczi, S., Ninagawa, K., Nishido, H. at al. 2012, Centr. Eur. Geol. 55(1), 33-48.

Nyquist, L. E., Bogard, D. D., Shih C.-Y., Greshake, A., Stöffler, D., \& Eugster, O. 2001, Space Sci. Rev., 96, 105-164.

Orlov, A. S., Mashukov, V. I., Rakitin, A. R., \& Novikova, E. S. 2012, J. Applied Spectr., 79(3), 484-489.

Parikh, S. J. \& Chorover, J. 2006, 22(20), 8492-8500.
Polgári, M., Gyollai, I., Bérczi, Sz., Veres, M., Gucsik, A., \& PálMolnár, E. 2017a, In: EANA17 European Astrobiology Association Exoplanets, Aarhus University press, 52-53.

Polgári, M., Gyollai, I., \& Bérczi, Sz. 2017b, In: Nagy, M., McIntosh, R. (Eds.) Átfogó kutatások a kabai meteoriton, 32, 8 (in Hungarian).

Polgári, M., Gyollai, I., \& Bérczi, Sz. 2019, Open Astron. (in press)

Polgári, M., Gyollai, I., Bérczi, Sz. 2018a, In: Nagy M., McIntosh R. (Eds.), Comprehensive Research on Kaba Meteorite, Acta GGM Debrecina Geology, Geomorphology, Physical Geography Series, Debrecen University Press, Special Issue, 55-69.

Polgári, M., Hein, J. R., Tóth, A. L., Pál-Molnár, E., Vigh, T., Bíró, L. et al. 2012a, Geology, 40(10), 903-906.

Polgári, M., Hein, J. R., Vigh, T., Szabó-Drubina, M., Fórizs, I., Bíró, L., et al. 2012b, Ore Geol. Revs, 47, 87-109.

Rajabzadeh, M. A., Haddad, F., Polgári, M., Fintor, K., Walter, H., Molnár, Z. et al. 2017, Ore Geol. Revs., 80, 229-249.

Rajasekar, A., Maruthamuthu, S., Muthukumar, N., Mohanan, S., Subramanian, P. \& Palaniswamy, N. 2005, Corros. Sci., 47(1), 257-271.

Skinner, H.C.W., 2005, Biominerals, Miner. Mag., 69 (5), 621 - 641. Takenouchi, A., Mikouchi, T., \& Yamaguchi, A., 2018, Met. Planet. Sci doi: 10.1111/maps.13120é.

Wright, I. P., Grady, M. M., \& Pillinger, C. T. 1988, Geochim. Cosmochim. Acta, 52(4), 917-924.

Wright, I. P., Grady, M. M., \& Pillinger, C. T. 1992, Geochim. Cosmochim. Acta, 56(2), 817-826.

Yanai, K. 1979, Mem. NIPR Res. Spec. Is., 12, 1-8. 